\title{
免疫化学的測定法による前立腺酸性フォスファターゼ
}

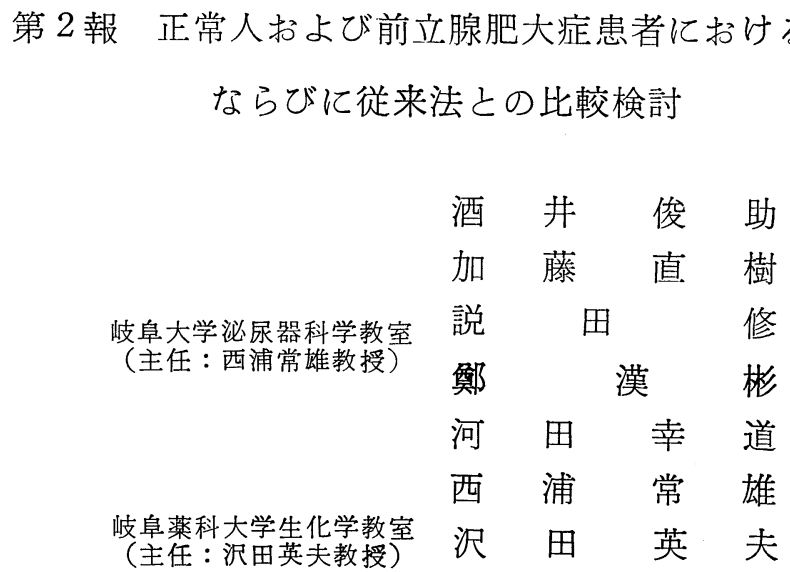

\section{DETECTION OF PROSTATIC ACID PHOSPHATASE \\ BY IMMUNOCHEMICAL METHOD}

II. Studies in Normal Men and Prostatic Benign Hypertrophy Patients, and

Comparison with Coventional Method

\author{
Shunsuke Sakai, Naoki Kato, Osamu Setsuda, Kanhin Tei, \\ Yukimichi Kawada and Tsuneo Nishiura \\ Department of Urology, Gifu University School of Medicine \\ (Director: Prof. T. Nishiura) \\ Hideo Sawada \\ Department of Biochemistry, Gifu College of Pharmacy
}

(Director: Prof. H. Sawada)

Specific anti-prostatic acid phosphatase serum was prepared with the prostatic acid phosphatase (PAPase) purified from prostatic adenoma. And a new immunochemical method for measuring the PAPase activity with anti-PAPase serum was devised. Using this new method, the PAPase activities in 7 cases of normal men, 7 cases of normal women and 54 cases of benign prostatic hypertrophy were determined. The total acid phosphatase (APase) activity and the PAPase activity inhibited by L-tartrate were determined. The total acid phosphatase (APase) activity and the PAPase activity inhibited by L-tartrate were determined simultaneously. The results were as follows:

1) When sera of patients with benign prostatic hypertrophy were allowed to stand at room temperature, the total APase activity decreased remarkably.

2) There were no differences between groups of normal men and women and group of benign prostatic hypertrophy in the total APase activity and the PAPase activity inhibited by L-tartrate. In addition, there were no differences in the ratio of the PAPase activity inhibited by L-tartrate against the total APase activity, while a high L-tartrate inhibited rate as about $48 \%$ was observed in normal women.

3) According to the immunochemical method, the PAPase activity was $0.33 \pm 0.29(\mathrm{n} \mathrm{moles} / \mathrm{min} / \mathrm{ml})$ in the group of benign prostatic hypertrophy. This value was slightly higher than those in normal men and women, but no significant difference was observed. In the ratio of the PAPase activity against the total APase activity, a similar result was observed.

4) No significant correlation was observed between weight of prostate and the PAPase activity determined by immunochemical method in 16 cases of benign prostatic hypertrophy. 
要旨 : 前立腺腺腫より前立腺酸性フォスファターゼ（PAPase）を精製し，これをウサギに免疫して得られた 抗血清より PAPase 活性のみを測定する免疫化学的方法をるちいて, 正常男性 7 例, 正常女性 7 例, 前立腺 肥大症患者54例の PAPase 活性を測定した。同時に従来の方法によつて全酵素活性值, L-tartrate 阻害による PAPase 活性も測定し比較検討した. 正常男女および前立腺肥大症患者血清の全酵素活性值, L-tartrate 阻害 による PAPase 活性值はいずれの群の間にも差を認めなかつた．全酵素活性值に対する L-tartrate 阻害の割 合に执いて，正常女性血清では $48 \%$ 前後の高い阻害率を認めた. 免疫化学的方法 (immunochemical method) による PAPase 活性值の前立腺肥大症患者 54 例に护ける平均は $0.33 \pm 0.29 \mathrm{n} \mathrm{moles} / \mathrm{min} / \mathrm{ml}$ であり，正常男性

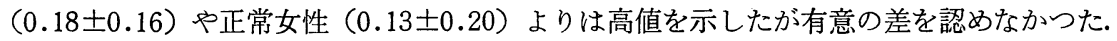

\section{緒言}

酸性フォスファターゼ (Acid Phosphatase : 以下, APase) は種々の臓器に存在するが，とくに前立腺に多 く存在し, 前立腺癌患者血清中に本酵素活性が上昇する ことから臨床上重要な指標とされる．前立腺酸性フォス ファターゼ (Prostatic Acid phosphatase : 以下, PAPase) のみの酵素活性を測定することは前立腺疾患患者の䛦断 扣よび治療など臨床上非常に有用で，特異的な PAPase 活性の測定が望まれる。

著者らは第 1 報に報告した如く，前立腺腺腫から PAPase を精製し，これより特異的な anti-PAPase 血清 を作ることができたが, anti-PAPase 血清による PAPase の免疫学的特異性を利用し血清中のPAPase 活性のみ を特異的に測定しうる可能性を認めた．今回この原理 を応用して新しいPAP ase 測定方法 (免疫化学的方 法, immunochemical method) を考案したのでその方 法を報告し，同時に，まず正常人特よび前立腺肥大症患 者について，従来の方法と比較検討した成績について報 告する。

\section{対象および従来法による研究方法}

対象とした症例は昭和53年 9 月より昭和54年12月まで の 1 年 3 力月間に岐皁大学医学部附属病院泌尿器科拈よ び関連病院の泌尿器科を受診した前立腺肥大症患者 54 例 と正常男性 7 例 おょ び 正常女性 7 例で，血清中の酸性 フォスファターゼの全酵素活性， L-tartrate 阻害による PAPase 活性, immunochemical method によるPAPase 活性について検討した．また，前立腺肥大症患者16例に ついて摘出標本の重量と immunochemical method によ るPAPase 活性の関係についても検討した。

な报，前立腺肥大症患者はいずれも以前に手術および 女性ホルモンなどの投与をらけていない症例のみを対象 とした。

前立腺触診, 前立腺マッサージ, 前立腺生検, 尿道カ テーテル操作などにより血清中の酸性フォスファターゼ
が上昇するとの報告(1)23)45(5)7)があることより，採血は それらの操作のない時期を選んだ.

血清中の酸性フォスファターゼの全醭素活性は Ohmori-Bessey-Lowry-Brock の方法に準じて行なつたが， $0.2 \mathrm{M}$ citrate buffer $(\mathrm{pH} 5.5) 1.0 \mathrm{ml}$, 蒸留水 $0.7 \mathrm{ml}$ K 血清 $0.1 \mathrm{ml}$ を加光，L-tartrate 阻害によるPAPase 酵素 活性は $0.2 \mathrm{M}$ citrate buffer $1.0 \mathrm{ml}$, 蒸留水 $0.5 \mathrm{ml}$ 飞血清 $0.1 \mathrm{ml}$ 特よび $0.2 \mathrm{M}$ L-tartrate $0.2 \mathrm{ml}$ を加え，いずれ も $20 \mathrm{mM}$ p-nitrophenylphosphate $0.2 \mathrm{ml}$ の基質で $37^{\circ} \mathrm{C} 30$ 分間酵素反応させ， $0.4 \mathrm{~N} \mathrm{NaOH} 1.0 \mathrm{ml}$ で酵素反応をと め, 同時に血清 blank を求め, 波長 $410 \mathrm{~nm}$ にセットし た光電分光光度計にそれぞれの吸光度をるとめ，検量線 より全酵素活性值招よび L-tartrate 阻害による PAPase 活性值をもとめた。

免疫化学的方法 immunochemical method

特異的な PAPase $と$ anti-PAPase の複合体が酸性側 で耐熱性であるという原理 ${ }^{8}$ を応用したもので，Table 1 に示す如く, human serum $0.5 \mathrm{ml}$, anti-PAPase serum $0.05 \mathrm{ml}, 0.2 \mathrm{M}$ citrate buffer $(\mathrm{pH} 5.5) 0.25 \mathrm{ml}, 0.9 \%$ $\mathrm{NaCl}$ solution $0.1 \mathrm{ml}$, 蒸留水 $0.1 \mathrm{ml}$ の計 $1 \mathrm{ml}$ を小試験管 に加光，これを test sample の系とし， control sample の系は human serum $0.5 \mathrm{ml}$, normal rabbit serum 0.05 $\mathrm{ml}, 0.2 \mathrm{M}$ citrate buffer $0.25 \mathrm{ml}, 0.9 \% \mathrm{NaCl}$ solution $0.1 \mathrm{ml}$, 蒸留水 $0.1 \mathrm{ml}$ の計 $1 \mathrm{ml}$ を小試験管に加兄た。さ らに anti-PAPase serum による酵素活性をのぞくため の test blank sample として, anti-PAPase serum 0.05 $\mathrm{ml}, 0.2 \mathrm{M}$ citrate buffer $0.25 \mathrm{ml}, 0.9 \% \mathrm{NaCl}$ solution $0.1 \mathrm{ml}$, 蒸留水 $0.6 \mathrm{ml}$ の計 $1 \mathrm{ml}$ を小試験管に加光, 同時 に, normal rabbit serum による酵素活性をのぞくための control blank sample として, normal rabbit serum 0.05 $\mathrm{ml}, 0.2 \mathrm{M}$ citrate buffer $0.25 \mathrm{ml}, 0.9 \% \mathrm{NaCl}$ solution $0.1 \mathrm{ml}$ ，蒸留水 $0.6 \mathrm{ml}$ の計 $1 \mathrm{ml}$ を小試験管に加光，いず れの系も $4{ }^{\circ} \mathrm{C}$ て 3 時間反応させた.

いずれの sample に抢いても，処理前と $56^{\circ} \mathrm{C}$ 熱処理 30 
Table 1 Immunochemical Determination of Prostatic Acid Phosphatase in Hnman Serum

\begin{tabular}{|c|c|c|c|c|}
\hline & test $(\mathrm{ml})$ & $\begin{array}{l}\text { control } \\
(\mathrm{ml})\end{array}$ & $\begin{array}{l}\text { test } \\
\text { blank }(\mathrm{ml})\end{array}$ & $\begin{array}{l}\text { control } \\
\text { blank }(\mathrm{ml})\end{array}$ \\
\hline human serum & 0.5 & 0.5 & - & - \\
\hline anti PAPase serum & 0.05 & - & 0.05 & - \\
\hline normal rabbit serum & - & 0.05 & - & 0.05 \\
\hline $0.2 \mathrm{M}$ citrate buffer $\mathrm{pH} 5.5$ & 0.25 & 0.25 & 0.25 & 0.25 \\
\hline $0.9 \% \mathrm{NaCl}$ soln. & 0.1 & 0.1 & 0.1 & 0.1 \\
\hline water & 0.1 & 0.1 & 0.6 & 0.6 \\
\hline \multicolumn{5}{|l|}{ incubation at $4^{\circ} \mathrm{C}$ for $1 \mathrm{hrs}$. } \\
\hline \multicolumn{5}{|c|}{ heat treatment at $56^{\circ} \mathrm{C}$ for $30 \mathrm{~min}$ and $2 \mathrm{hrs}$. } \\
\hline \multicolumn{5}{|l|}{$0.2 \mathrm{ml}$ of each sample } \\
\hline \multicolumn{5}{|c|}{$\begin{array}{ll}\begin{array}{l}0.2 \mathrm{M} \text { citrate buffer } \mathrm{pH} \\
\text { water }\end{array} & \begin{array}{l}1.0 \mathrm{ml} \\
0.1 \mathrm{ml}\end{array} \\
\end{array}$} \\
\hline \multicolumn{5}{|c|}{ pre incubation at $37^{\circ} \mathrm{C}$ for $3 \mathrm{~min}$. } \\
\hline \multicolumn{5}{|c|}{$20 \mathrm{mM}$ p- nitrophenyl phosphate $0.2 \mathrm{ml}$} \\
\hline \multicolumn{5}{|c|}{ incubation at $37^{\circ} \mathrm{C}$ for $30 \mathrm{~min}$. } \\
\hline $0.4 \mathrm{M} \mathrm{NaOH}$ & $.0 \mathrm{ml}$ & & & \\
\hline at $410 \mathrm{~nm}$. & & & & \\
\hline
\end{tabular}

分間後, 120 分間後の sample $0.2 \mathrm{ml}$ （血清量 $0.1 \mathrm{ml}$ ) を $0.2 \mathrm{M}$ citrate buffer $1.0 \mathrm{ml}$, 蒸留水 $0.6 \mathrm{ml}$ に加兄, 基質 として $20 \mathrm{mM} \rho$-nitrophenylphosphate $0.2 \mathrm{ml}$ をもちいて $37^{\circ} \mathrm{C}$ にて30分間酵素反応させ， $0.4 \mathrm{~N} \mathrm{NaOH} 1.0 \mathrm{ml}$ で反 応をとめ, 同時にそれぞれの系の sample および test blank, control blank に打ける血清 blankをもとめ, 波 長 $410 \mathrm{~nm}$ にセットした光電分光光度計にてそれぞれの 吸光度をもとめた。

anti-PAPas serum 添加の系, normal rabbit serum 添 加の系, test blank, control blank に护ける処理前, 熱 処理30分間後, 120分間後の吸光度からそれぞれの系に お壮る血清 blank の吸光度の差をもとめたのち, さら に anti-PAPase serum 添加の系では処理前, 熱処理30 分間後, 120分間後の吸光度から test blank に打ける それぞれの時間の吸光度の差をもとめ, normal rabbit serum 添加の系でも同様に control blank の差をもとめ た. それらよりもとめた anti-PAPase 血清添加の test sample の系に和ける処理前の吸光度に対する熱処理30 分後, 120分間後におケる吸光度の比率をもとめ, 同様 に normal rabbit serum 添加の control sample の系に おいても吸光度の比率をもとめた. 第 1 報で報告した如
く，抗血清添加の場合には $56^{\circ} \mathrm{C}$ で熱処理すると 2 時間 後も精製 PAPase 活性が $100 \%$ 残存し, normal rabbit serum 添加では30分間の熱処理により活性が速やかに消 失することによりそれぞれの系の熱処理30分間後, 120 分間後に拈ける吸光度の比率をもとめ, その平均值を酸 性フォスファターゼの全酵素活性值に対する PAPase 活 性值の割合とした，さらに全酵素活性值に PAPase の割 合を乗じて immunochemical method による PAPase 活 性値とした。

血清中の酸性フォスファターゼの全酵素活性値, L-tartrate 阻害による PAPase 活性值および immunochemical method による PAPase 活性値の単位は, 血清 $1 \mathrm{ml}$ あたり，酵素反応時間 1 分あたりの $\rho$-nitrophenol の nmoles 単位 (acid phosphatase activity is expressed in nmoles of $\rho$-nitrophenol produced per minute per $\mathrm{ml}$ ) で示し, 以後単位は省略する。

なお，各測定值の群別比較は原則として $\mathbf{t}$ 検定による 推計学的検討によつて有意差の有無を検定し, 有意水準 は $5 \%$ と考えた。また，群間の相関関係は Pearson の相 関係数を使用した。 
Table 2 Tatal APase Activity after 12hrs. and 24hrs. at Room Temperature and after one Month at $-20^{\circ} \mathrm{C}$ in sera of BPH Patients

\begin{tabular}{c|c|r|r|c}
\hline No. & $\begin{array}{c}\text { Total Activity } \\
\text { at Ohr. }\end{array}$ & $\begin{array}{c}\text { after 12 hrs. } \\
\mathrm{n} \text { moles (\%) }\end{array}$ & $\begin{array}{c}\text { after 24 hrs. } \\
\mathrm{n} \text { moles (\%) }\end{array}$ & $\begin{array}{c}\text { after one month } \\
\text { at }-20^{\circ} \mathrm{C}\end{array}$ \\
\hline 1 & $7.06 \mathrm{n}$ moles & $5.78(18.20)$ & $3.40(51.88)$ & $7.25 \mathrm{n}$ moles \\
\hline 2 & 8.06 & $6.38(20.78)$ & $5.13(36.36)$ & 7.75 \\
\hline 3 & 6.78 & $5.21(23.09)$ & $3.15(53.49)$ & 6.54 \\
\hline 4 & 7.67 & $5.06(33.97)$ & $3.94(48.67)$ & 7.92 \\
\hline 5 & 5.78 & $4.43(23.29)$ & $3.80(34.25)$ & 5.71 \\
\hline 6 & 4.06 & $3.29(19.05)$ & $2.46(39.40)$ & \\
\hline 7 & 6.39 & $5.33(16.52)$ & $3.51(45.12)$ & \\
\hline 8 & 5.83 & $4.82(17.32)$ & $3.63(37.81)$ & \\
\hline 9 & 4.44 & $3.23(27.17)$ & $2.66(39.99)$ & \\
\hline 10 & 5.56 & $5.00(9.96)$ & $3.45(37.97)$ & \\
\hline Ave. & 6.16 & $4.85(20.94)$ & $3.51(42.49)$ & 7.03 \\
\hline & & & & \\
\hline
\end{tabular}

成

精製 PAPase は熱, $\mathrm{pH}$ に非常に弱いことは第 1 報に て報告しているが，血清中の酸性フォスファターゼも同 様に Table 2に示す如く, 10例の前立腺肥大症患者血清 に打いて血清分離直後，室温放置12時間，24時間後のそ れぞれの酸性フォスファターゼの全酵素活性值を測定す ると，12時間後に平均 $21.0 \%$ の失活，24時間に $42.5 \%$ の 失活を認めた. しかし, 同患者血清 5 例について血清分

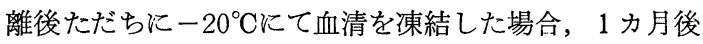
に再検してもほとんど活性の低下を認めなかつた．以上 より血清分離は冷却遠心器にて抗こな，血清保存は実 験に供するまでー $20^{\circ} \mathrm{C}$ にて保存しておいた。

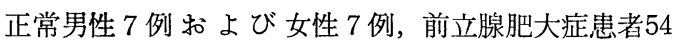
例の血清中の酸性フォスファターゼの全酵素活性,

L-tartrate 阻害による PAPase 活性, immunochemical method による PAPase 活性についての成績は Table $3 ， 4$ に示した。

凝血の際に血小板より遊出してくる血小板由来の APase をはじめ前立腺由来など種々の臓器由来の APase を含んでいる全酵素活性に和いては，正常男性 7 例の平 均は5.89土1.30, 正常女性 7 例の平均は6.05士2.35, 前

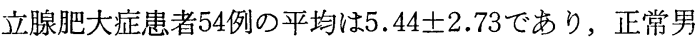
性血清, 正常女性血清, 前立腺肥大症患者の比較検討に おいてはいずれも有意の差を認めなかつたが，正常女性 血清が前立腺肥大症患者および正常男性血清よりやや高 值を示している。
第 1 報に打いて報告した如く，精製 PAPase に扣い て L-tartrate 濃度は0.2M にて95\%の阻害を認めるが, $0.2 \mathrm{M}$ によるL-tartrate 阻害による前立腺性酸性フォス ファターゼの酵素活性に括いては, 正常男性 7 例の平均

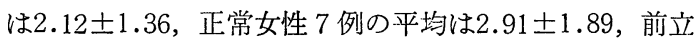
腺肥大症患者37例の平均は2.70土2.08であり，正常男性 血清, 正常女性血清, 前立腺肥大症患者の比較検討にお いてはいずれも有意の差を認めなかつた. 正常女性血清 は全酵素活性同様に前立腺肥大症患者よりも若干高值を 示している.なお，前立腺肥大症患者のらちもつとも高 值を示している症例は7.94であり，もつとも低值の症例 は0.06, 正常女性血清においてもつとも高值の症例は 5.72 ，もつとも低值の症例は0.78であつた。

次に全酵素活性值に対する L-tartrate 阻害の割合につ いて検討すると，正常男性血清の平均は35.66士16.82\% であり，正常女性血清においてもつとも阻害率の高い症 例は $51.3 \%$ むり, 平均して $48 \%$ 前後の阻害率を認め た。前立腺肥大症患者においてはもつとも高い阻害率を 認めた症例は $80.8 \%$ であ，もつとも低い阻害率を認め た症例は1.4\%しかなくかなりのバラツキを認めてお り平均して $41.02 \pm 21.26 \%$ の阻害率を認めた。

immunochemical method による前立腺性酸性フォス ファターゼ (PAPase) の酵素活性の検討では，正常男 性 7 例の平均は $0.18 \pm 0.16$, 正常女性 7 例の平均は 0.13 \pm 0.20 , 前立腺肥大症患者54例の平均は0.33土0.29であ り, 正常男性血清, 正常女性血清, 前立腺肥大症患者の 
Table 3 Acid Phosphatase Activity in Sera of Normal Adult

\begin{tabular}{c|l|c|c|c|c|c}
\hline No. & Sex & $\begin{array}{c}\text { Total } \\
\text { activity }\end{array}$ & $\begin{array}{c}\text { Activity } \\
\text { inhibited dy } \\
\text { L-tartrate } \\
(\mathrm{B})\end{array}$ & $\begin{array}{c}\text { Activity } \\
\text { stabilized by } \\
\text { anti-PAPase } \\
(\mathrm{C})\end{array}$ & $\begin{array}{c}\frac{(\mathrm{B})}{(\mathrm{A})} \times 100 \\
(\%)\end{array}$ & $\begin{array}{c}\frac{(\mathrm{C})}{(\mathrm{A})} \times 100 \\
(\%)\end{array}$ \\
\hline 1 & male & 4.61 & 0.56 & 0.14 & 12.1 & 3.0 \\
\hline 2 & male & 4.39 & 1.78 & 0.05 & 40.5 & 1.1 \\
\hline 3 & male & 5.11 & 1.12 & 0.26 & 21.9 & 5.1 \\
\hline 4 & male & 6.81 & 2.78 & 0.51 & 40.8 & 7.5 \\
\hline 5 & male & 5.71 & 3.12 & 0.11 & 54.6 & 1.9 \\
\hline 6 & male & 7.85 & 4.37 & 0.07 & 55.8 & 0.9 \\
\hline 7 & male & 4.64 & 1.11 & 0.09 & 23.9 & 1.9 \\
\hline 8 & female & 8.56 & 5.11 & 0 & 59.7 & 0 \\
\hline 9 & female & 4.44 & 2.06 & 0 & 46.4 & 0 \\
\hline 10 & female & 7.44 & 3.00 & 0.43 & 40.3 & 5.8 \\
\hline 11 & female & 9.33 & 5.72 & 0.10 & 61.3 & 1.1 \\
\hline 12 & female & 5.00 & 2.56 & 0.07 & 51.2 & 1.4 \\
\hline 13 & female & 4.00 & 1.12 & 0.12 & 28.0 & 3.0 \\
\hline 14 & female & 3.56 & 0.78 & 0.04 & 21.9 & 1.2 \\
\hline$*:$ Acid phosphatase activity in expressed in n moles of & & \\
\hline
\end{tabular}

比較検討においてはいずれも有意の差を認めなかつた。 前方腺肥大症患者が正常男性血清, 正常女性血清に比し 若干高値を示して和り，正常男性血清に拈いてはもつと も高值の症例は0.51, 低值の症例は 0.05 , 正常女性血清 に怙いてはもつとも高值の症例は 0.43 , 低值の症例は 0 で，前立腺肥大症患者のらちもつとも高值を示した症例 は1.10, もつとも低值の症例は0であつた。

次全酵素活性值に対する immunochemical method による PAPase 活性の割合について検討すると, 正常 男性 7 例の平均は $3.06 \pm 2.42 \%$, 正常女性 7 例の平均は $1.79 \pm 2.04 \%$, 前立腺肥大症患者 54 例 の 平均は $5.82 \pm$ 4.37\%であつた. 前立腺肥大症患者の亚均がもつとも高 值を示しているが, 正常男性血清, 正常女性血清, 前立 腺肥大症患者の比較検討においてはいずれも有意の差を 認めなかつた。

な敃，正常男性血清のうちもつとも高値を示している 症例は $7.5 \%$, 低值を示している症例は0.9\%で, 正常女 性血清飞怙いて高值は $5.8 \%$, 低值は $0 \%$ で, 前立腺肥 大症患者のらちもつとも高値を示している症例は 18.7 \%, るつとも低值を示している症例は $0 \%$ であつた。

次洋前立腺肥大症患者37例飞ついて， L-tartrate 阻害
による PAP ase 活性值と immunochemical method に よるPAPase 活性値の相関関係を Pearson の相関係数 をもちいて検討すると，両者間の相関係数は0.3886と低 く(Fig. 1)，L-tartrate 阻害による PAPase 活性值が 7.94 とつとも高值を示した症例は immunochemical method によるPAPase 活性では0.04しか認めず, L-tartrate による PAPase 活性值が0.06ともつとも低值 を示した症例は immunochemical method によるPAPase 活性值が0.16であつた．また同様に全酵素活性值に対す る L-tartrate 阻害による PAPase 活性值の割合と immunochemical method によるPAPase 活性值の割合の相 関関係の検討でも，相関係数は 0.0734 と低值を示した

(Fig. 2).

前立腺肥大症患者16例飞ついて，その摘出標本の重量 (Table 4) と immunochemical method による PAPase 活性值および全酵素活性值に対する immunochemical method によるPAPase 活性値の割合について検討し た。重量の最高は83gr であり, その症例の PAPase 活 性値は0.11, PAPase 活性値の割合は $1.2 \%$ であつた。一 方, 最低重量は2gr でありその症例の PAPase 活性值は 0.16, PAPase 活性值の割合は3.6\%であつた. PAPase 
活性値が1.10と最高値を示した症例の重量は20gr，活 性值が最低值を示した症例の重量は15gr であり，また PAPase 活性値の割合が $13.2 \%$ と最高値を示した症例の 重量は18gr，最低值を示した症例の重量は83gr であつ
た。 以上より摘出標本の重量と PAPase 活性值および 全酵素活性値 占める PAPase 活性值の割合との間に は比例関係を認めなかつた。

Table 4 Acid Phosphatase Activity in Sera of BPH

\begin{tabular}{|c|c|c|c|c|c|c|}
\hline No. & $\begin{array}{l}\text { Total } \\
\text { activity * (A) }\end{array}$ & $\begin{array}{l}\text { Activity } \\
\text { inhibited by } \\
\text { L- tartrate * } \\
\text { (B) }\end{array}$ & $\begin{array}{l}\text { Activity } \\
\text { stabilized by } \\
\text { anti-PAPase * } \\
\text { (C) }\end{array}$ & $\begin{array}{c}\frac{(B)}{(A)} \times 100 \\
(9)\end{array}$ & $\begin{array}{l}\frac{(\mathrm{C})}{(\mathrm{A})} \times 100 \\
(\mathscr{6})\end{array}$ & $\begin{array}{l}\text { Weight } \\
\text { (gr) }\end{array}$ \\
\hline 1 & 7.67 & 3.67 & 0.35 & 47.85 & 4.6 & 30 \\
\hline 2 & 5.78 & 0.95 & 0.46 & 16.44 & 8.0 & 5 \\
\hline 3 & 11.72 & 7.56 & 0.73 & 64.51 & 6.2 & 10 \\
\hline 4 & 12.45 & 3.00 & 0.29 & 24.10 & 2.3 & 12 \\
\hline 5 & 6.39 & 2.50 & 0.17 & 39.12 & 2.7 & 12 \\
\hline 6 & 4. 39 & 0.06 & 0.16 & 1.37 & 3.6 & 2 \\
\hline 7 & 5.00 & 2.11 & 0.09 & 42.20 & 1.8 & 15 \\
\hline 8 & 8.83 & 5.22 & 0.11 & 59.12 & 1.2 & 83 \\
\hline 9 & 7.00 & 3.11 & 0.32 & 44.43 & 4.6 & 41 \\
\hline 10 & 9.82 & 6.32 & 1.10 & 64.36 & 11.2 & 20 \\
\hline 11 & 7.49 & 1.94 & 1.01 & 25.90 & 13.5 & 12 \\
\hline 12 & 4.06 & 1.36 & 0.13 & 33.50 & 3.2 & 18 \\
\hline 13 & 5.83 & 0.44 & 0.16 & 7.55 & 2.7 & 22 \\
\hline 14 & 5.50 & 1.72 & 0.73 & 31.27 & 13.2 & 18 \\
\hline 15 & 6.44 & 3.33 & 0.16 & 51.71 & 2.5 & 21 \\
\hline 16 & 7.06 & 3.72 & 0.15 & 52.64 & 2.1 & \\
\hline 17 & 8.06 & 4.06 & 0.62 & 50.37 & 7.7 & \\
\hline 18 & 5.50 & 4.15 & 0.40 & 75.45 & 7.3 & \\
\hline 19 & 10.39 & 7.83 & 0.85 & 75.36 & 8.2 & \\
\hline 20 & 9.83 & 7.94 & 0.04 & 80.77 & 0.4 & \\
\hline 21 & 6.78 & 1.95 & 0.55 & 28.76 & 8.1 & \\
\hline 22 & 11.06 & 1.00 & 0.72 & 9.04 & 6.5 & \\
\hline 23 & 1.67 & 1.34 & 0.07 & 80.24 & 4.1 & \\
\hline 24 & 5.57 & 0.78 & 0.10 & 14.00 & 1.8 & \\
\hline 25 & 4.06 & 1.12 & 0.29 & 27.59 & 7.2 & \\
\hline 26 & 3.39 & 0.78 & 0.10 & 23.00 & 1.8 & \\
\hline 27 & 4.44 & 0.50 & 0.14 & 11.26 & 3.1 & \\
\hline 28 & 5.56 & 1.89 & 0.20 & 33.99 & 3.5 & \\
\hline
\end{tabular}

* : Acid phosphatase activity is expressed in $n$ moles of $\mathrm{P}$ - nitrophenol produced per minute per $\mathrm{ml}$. 
Table 4 (continued)

\begin{tabular}{|c|c|c|c|c|c|c|}
\hline No. & $\begin{array}{l}\text { Total } \\
\text { activity } *(A)\end{array}$ & $\begin{array}{l}\text { Activity } \\
\text { inhibited by } \\
\text { L- tartrate * } \\
\text { (B) }\end{array}$ & $\begin{array}{l}\text { Activity } \\
\text { stabilized by } \\
\text { anti-PAPase * } \\
\text { (C) }\end{array}$ & $\begin{array}{c}\frac{(\mathrm{B})}{(\mathrm{A})} \times 100 \\
(9)\end{array}$ & $\begin{array}{c}\frac{(\mathrm{C})}{(\mathrm{A})} \times 100 \\
(9)\end{array}$ & $\begin{array}{c}\text { Weight } \\
\text { (gr) }\end{array}$ \\
\hline 29 & 7.11 & 3.22 & 0.80 & 45.29 & 11.2 & \\
\hline 30 & 3.94 & 1.55 & 0.09 & 39.34 & 2.5 & \\
\hline 31 & 4.17 & 1.45 & 0.09 & 34.77 & 2.1 & \\
\hline 32 & 7.79 & 2.96 & 0.62 & 38.00 & 8.0 & \\
\hline 33 & 5.56 & 2.78 & 0.45 & 50.00 & 8.0 & \\
\hline 34 & 2.50 & 0.49 & 0.06 & 19.60 & 2.3 & \\
\hline 35 & 1.61 & 0.78 & 0.06 & 48.45 & 3.8 & \\
\hline 36 & 5.06 & 3.06 & 0.52 & 60.47 & 10.2 & \\
\hline 37 & 4.89 & 3.22 & 0.13 & 65.90 & 2.6 & \\
\hline 38 & 0.56 & & 0 & & 0 & \\
\hline 39 & 3.72 & & 0.30 & & 8.1 & \\
\hline 40 & 4.67 & & 0.87 & & 18.7 & \\
\hline 41 & 1.72 & & 0.19 & & 11.1 & \\
\hline 42 & 4.67 & & 0.48 & & 10.3 & 25 \\
\hline 43 & 2.78 & & 0.33 & & 11.9 & \\
\hline 44 & 3.28 & & 0.26 & & 7.8 & \\
\hline 45 & 3.44 & & 0.01 & & 0.3 & \\
\hline 46 & 3.89 & & 0.32 & & 8.2 & \\
\hline 47 & 8.28 & & 0.94 & & 11.3 & \\
\hline 48 & 2.17 & & 0.02 & & 0.8 & \\
\hline 49 & 1.83 & & 0.03 & & 1.7 & \\
\hline 50 & 4.17 & & 0.03 & & 0.7 & \\
\hline 51 & 4.67 & & 0.19 & & 4.1 & \\
\hline 52 & 2.56 & & 0.02 & & 0.7 & \\
\hline 53 & 2.17 & & 0.31 & & 14.4 & \\
\hline 54 & 4.67 & & 0.48 & & 10.3 & \\
\hline
\end{tabular}

* : Acid phosphatase activity is expressed in n moles of $\mathrm{P}$ - nitrophenol produced per minute per $\mathrm{ml}$.

\section{考按}

血清中の前立腺性酸性フォスファターゼの酵素活性の みを特異的飞測定し，前立腺由来の APase と赤血球ま たは他の組織由来の APase を区別することは前立腺疾 患の生化学的診断に重要な意義をもつものである.

血清中の PAPase 活性を測定する方法には種々の方法 が見いだされているが89910)，現在まで特異的に PAPase
のみの酵素活性值を測定する方法は確立されていない。 著者らの測定法は第 1 報 ${ }^{11)}$ の報告のごとく，抗血清の 免疫学的特異性を利用して特異的に血清中の PAPase の 酵素活性值のみを測定する方法で，同じく免疫学的測定 法として特異的に酵素を測定する counterelectrophoresis $^{12)}$ や radioimmunoassay ${ }^{13) 14) 15)}$ とよる方法があるが, これらは酵素自身の量を測定するもので，これに対して 
Fig. 1 Correlation between PAPase Activity Determined by Immunochemical Method and Ltartrate Method

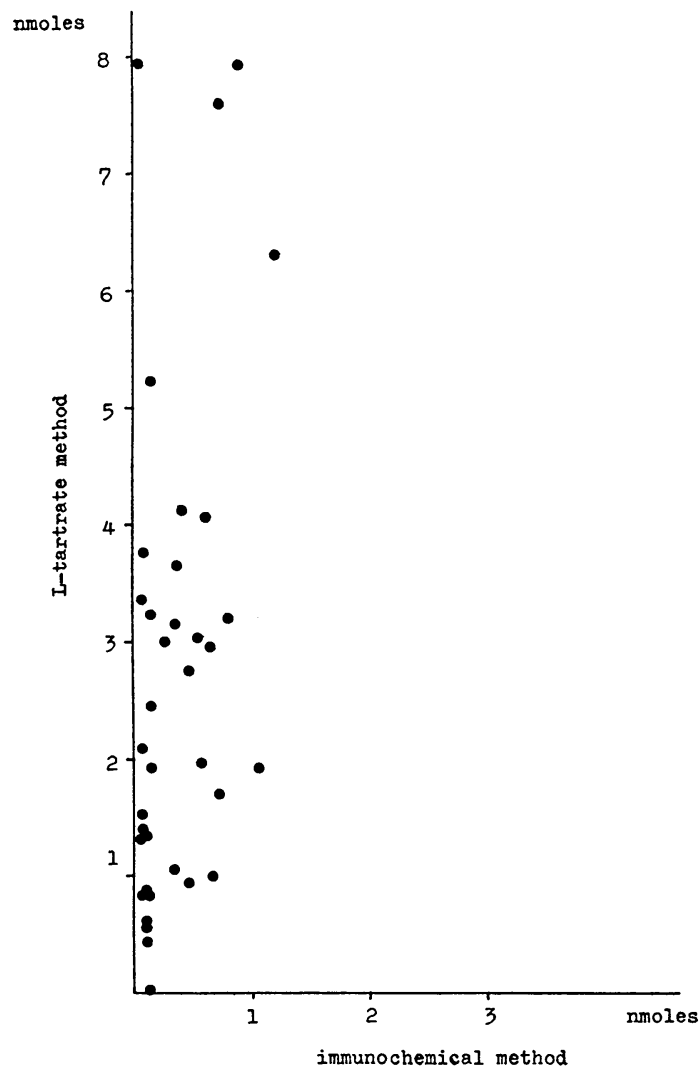

本法は醳素活性を測定するといら意味でこれらとは異な り非常に意義がある.今後の検討において酸性フォスフ アタービが高值を示す前立腺癌患者の血清中の PAPase を測定し対比するために，まず正常人おうよび前立腺肥大 症患者における PAPase 活性值および全酵素活性值に対 する PAPase 活性値の割合を検討した。

精製 PAPase に関しては熱， $\mathrm{pH}$ に弱いことは第 1 報 に報告したと扣りで，血清中の APase も不安定であ り，採血後の血清の室温放置により $\mathrm{pH}$ の上昇とともに 速やかに失活するとの報告 ${ }^{16)}$ があるように，今回著者ら の検討においても非常に弱く, 血清分離直後に室温放置 によりかなりの酵素活性の失活を認めているが， $-20^{\circ} \mathrm{C}$ 保存においては1 カ月後もほとんど活性の低下を認めて いない. しかし, 普通の遠心器にての血清分離は遠心の 時の熱発生により酵素活性の失活を認めることより, 冷 却遠心器にて血清分離の必要があり, 保存する場合には
Fig. 2 Correlation between Ratio of PAPase Activity Determined by Two Methods in Total APase Activity

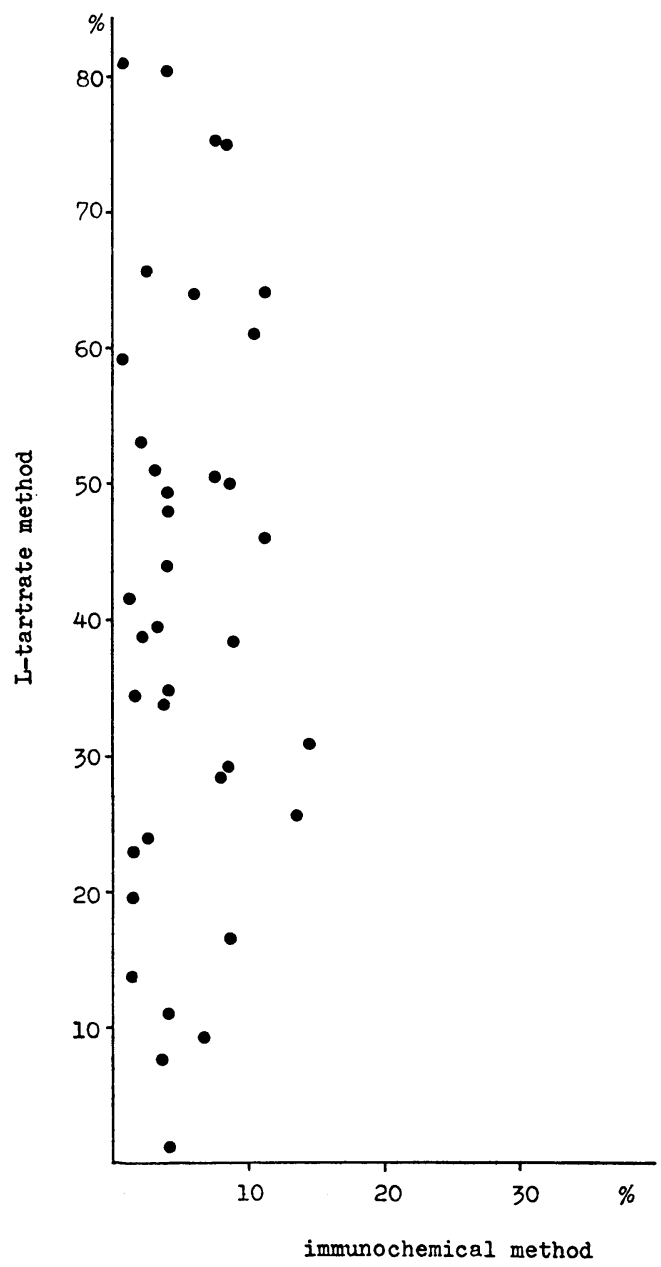

$-20^{\circ} \mathrm{C}$ 以下の保存が必要と思われる.

血清中の前立腺酸性フォスファターゼの酵素活性の測 定には，現在もなお診断の補助として有用とされる in hibitor である L-tartrateを併用する方法 ${ }^{8)}$ が一般的に

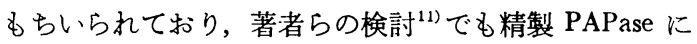
対して0.2M 以上の L-tartrate は95\%近くの阻害を認め ており，PAPase に対して強い阻害作用を認めている. しかし，L-tartrate による阻害は PAPase のみに特異的 でなく, 他の蔵器由来の APase も阻害することが知ら れており，今回の検討でも女性血清においてもつとも高 い阻害率を認めている症例は61.3\%もあり, 平均すると 44\%と高い阻害率を認めており，やはり前立腺由来の酸 
性フォスファターゼのみを阻害しているとは考兄られ ない。これに対し，immunochemical method による PAPase 活性值扣よび 全酵素活性值に対する割合は, L-tartrate 阻害の場合と同じ血清量, 同じ反応時間でも かなり低値を示すのは， L-tartrate 阻害では前立腺由来 の酸性フォスファターゼ以外にもかなりの阻害を認める ことにより差が生じたものと考光られる．前立腺肥大症 患者に打ける immunochemical method によるPAPase 活性值は正常男性掞よび正常女性血清より若干高值を示 すがやはり全体として低值を示すことより, 前立腺由来 の酸性フォスファターゼ自身は他臟器由来の酸性フォス ファターゼと比較すると低いものと考光られる．とくに 女性血清では L-tartrate 阻害に沶いては44\%の阻害を認 めるのに対し, immunochemical method の PAPase 活 性の割合では1.8\%しか認めていない。

一方, 前立腺肥大症患者飞拈ける L-tartrate 阻害に よるPAPase 活性值とその割合拉よび immunochemical method によるそれらの相関関係ではいずれも相関係数 は低く，L-tartrate 阻害による PAPase 活性でバラッキ を認めた前立腺肥大症患者飞括いて，immunochemical method Kよる PAPase 活性値の平均は0.33士0.29であ り，もつとも高值は 1.10 , 低值は 0 であり，1.0を越光 る症例は 54 例中 2 例で 1.5 を越光る症例は 1 例も認めて おらず, 全活性值に対する PAPase 活性值の割合の平均 も5.82 4 . $37 \%$ であり, 約 $5 \%$ 前後しか認めず15\%を越 光る症例は 54 例中 1 例之少なく, むつとも高い症例でも $18.7 \%$ であり $20 \%$ 以上を越える症例は現在までの検討で は認めていないささらに前立腺肥大症患者の摘出標本の 重量と PAPase 活性值执よびその割合の関係に括いても 重量に比例して PAPase 活性が増加するものでないこと が判明した。

以上より前立腺肥大症患者と正常男性血清および正常 女性血清に扣いては PAPase 活性值抽よび全酵素活性值 に対する割合において有意の差はなく，また前立腺肥大 症患者の血清中の PAPase 活性值は低く, 全活性值に刘 する割合も低いことが判明した。

これらの成績は酸性フォスファターゼが高值を示す前 立腺癌患者との比較が可能であることを示唆しているも のと思われる。

\section{結語}

1）前立腺腺腫から 前立腺酸性フォスファターゼ (PAPase)を精製し，これによつて特異的な抗前立腺 酸性フォスファターゼ血清を作製し，これを用いた新
しい PAPase 活性の測定法 (免疫化学的方法 immuno chemical method) を考案した.

2）この方法を用いて，正常男性 7 例，正常女性 7 例, 前立腺肥大症患者54例について PAPase 活性を測 定した。 また同時に従来の方法によつて全醅素活性值， L-tartrate 阻害による PAPase 活性も測定し比較検討し た。

3）血清中の酸性フォスファターゼが熱に弱いことは 従来よりよく知られているが，前立腺肥大症患者沈いい ても血清の室温放置により全酵素活性の明らかな低下を 認めた。

4）正常男女および前立腺肥大症患者血清の全酵素活 性値，L-tartrate 阻害による PAPase 活性值はいずれの 群の間にも差を認めなかつた．全䤃素活性值に対する L-tartrate 阻害の割合に括いてもいずれの群の間にも差 を認めなかつたが，正常女性血清に执いて48\%前後の高 い阻害率を認めた。

5) immunochemical method によるPAPase 活性值 の前立腺肥大症患者 54 例飞括ける平均は0.33土0.29であ $\eta$, 正常男性 $(0.18 \pm 0.16)$ や正常女性 $(0.13 \pm 0.20)$ よりは高值を示したが有意の差を認めなかつた。 また， 全酵素活性值に対する immunochemical method による PAPase 活性值の割合も同様に差を認めなかつた.

6）前立腺肥大症患者16例に扮いて，摘出前立腺の重 量と immunochemical method によるPAPase 活性值拉 よびその全酵素活性値に占める割合を検討したが，摘出 重量と PAPase 活性の間には有意の関係を認めなかつ た.

本論文の要旨は第68回日本泌尿器科学総会扰よび第31 回日本泌尿器科学西部連合総会において発表した。

\section{文献}

1) Kendall, A.R.: Acid phosphatase elevation following prostatic examination in the earlier diagnosis of prostatic carcinoma. J. Urol., 86, 442-449, 1961.

2) Dybkaer, R. and Jensen, G.: Acid serum phosphatase levels following massage of the prostate. Scan. J. Clin. Lab. Invest., 10, 349-354, 1958.

3) Whitmore, W.F. and Woodard, H.Q.: The effects of prostatic surgery on the level of serum acid glycerophosphatase. J. Urol., 74, 809817, 1955.

4) Stewart, C.B., Sweetser, T.H. and Delory, G.E.: A case of benign prostatic hypertrophy with recent infarcts and associated high serum 
acid phosphatase. J. Urol., 63, 128-131, 1950.

5) Glenn, J.F. and Spanal, D.J.: Serum acid phosphatase and the effect of prostatic massage. J. Urol., 82, 240-242, 1959.

6) Nadsen, P.O. and Naber, K.G.: The importance of the pressure in the prostatic fossa and absorption of irrigating fluid during transurethral resection of the prostate. J. Urol., 109, 446-452, 1973.

7) Greene, F.T. and Thompson, I.M.: The effects of various manipulations on serum phosphatase levels in benign disease. J. Urol., 112, 232236, 1974.

8) Fischman, W.H. and Lerner, F.A.: A method for estimating serum acid phosphatase of prostatic origin. J. Biol. Chem., 200, 89-97, 1953.

9) Roy, A.V., Brower, M.E. and Hayden, J.E.: Sodium thymolphthalein monophosphate, a new acid phosphatase substrate with greater specificity for the prostatic enzyme in serum, Clin. Chem., 17, 1093-1102, 1971.

10) Babson, A.L. and Read, P.A.: A new assay for prostatic acid phosphatase in serum. Am. J. Clin. Pathol., 32, 88-91, 1959.

11) 酒井俊助, 加藤值樹, 河田幸道, 西浦常雄, 沢
田英夫 : 免疫化学的測定法による前立腺酸性 フォスファターゼ. 第 1 報, 免疫化学的測定法 確立に関する基礎的検討. 日泌尿会誌, 投稿中.

12) Chu, T.M., Wang, M.C., Scott, W.W., Gibbons, R.P., Johnson, D.E., Schmidt, J.D., Loening, S.A., Prout, G.R., and Murphy, G.P.: Immunochemical detection of serum prostatic acid phosphatase. Invest. Urol., 15, 319-323, 1978.

13) Foti, A.G., Herschman, H. and Cooper, J.F.: A solid-phase radioimmunoassay for human prostatic acid phosphatase. Cancer Research, 35, 2446-2452, 1975.

14) Foti, A.G., Cooper, J.F., Herschman, H. and Malvaey, R.R.: Detection of prostatic cancer by solid-phase radioimmunoassay of serum prostatic acid phosphatase. N. Engl. J. Med., 297, 1357-1361.

15) Gittes, R.: Acid phosphatase reappraised. N. Engl. J. Med., 297, 1398-1399, 1977.

16) Woodard, H.Q.: A note on the inactivation by heat of acid glycerophosphatase in alkaline solution. J. Urol., 65, 688-692, 1951.

(1981年 6 月 15 日受付) 